\title{
The Influence of a Second Metal on the Ni/SiC Catalyst for the Methanation of Syngas
}

\author{
Lanlan Song*, Yue Yu**,ं, Xiaoxiao Wang***, Guoqiang Jin*, Yingyong Wang* and XiangYun Guo*, \\ *State Key Laboratory of Coal Conversion, Institute of Coal Chemistry, Taiyuan 030001, PR China \\ **Lin Yi Academy of Technology Cooperation and Application, Linyin 276000, PR China \\ ***Taiyuan University of Science and Technology, Taiyuan 030024, PR China \\ (Received 26 February 2014; Received in revised form 31 March 2014; accepted 2 April 2014)
}

\begin{abstract}
The catalytic performance of silicon carbide supported nickel catalysts modified with or without second metal $(\mathrm{Co}, \mathrm{Cu}$ and $\mathrm{Zn})$ for the methanation of $\mathrm{CO}$ has been investigated in a fixed-bed reactor using a feed consisting of $25 \% \mathrm{CO}$ and $75 \% \mathrm{H}_{2}$ without any diluent gas. It has been found that the introduction of Co species can clearly improve the catalytic activity of $\mathrm{Ni} / \mathrm{SiC}$ catalyst, whereas the addition of $\mathrm{Cu}$ or $\mathrm{Zn}$ can result in a significant decrease in the catalytic activity. The characterizations by means of XRD, TEM, XPS, CO-TPD and $\mathrm{H}_{2}$-TPR indicate that the addition of Co could decrease the particle size of active metal, increase active sites on the surface of methanation catalyst, improve the chemisorption of $\mathrm{CO}$ and enhance the reducibility of methanation catalysts. Additionally, the special interaction between Co species and Ni species is likely favorable for the dissociation of adsorbed $\mathrm{CO}$ on the surface of catalyst, and this may also contribute to the high activity of $5 \mathrm{Co}-\mathrm{Ni} / \mathrm{SiC}$ catalyst for $\mathrm{CO}$ methanation reaction. For $5 \mathrm{Cu}-\mathrm{Ni} / \mathrm{SiC}$ catalyst and $5 \mathrm{Zn}-$ $\mathrm{Ni} / \mathrm{SiC}$ catalyst, $\mathrm{Cu}$ and $\mathrm{Zn}$ species could cover partial nickel particles and decrease the chemisorption amount of $\mathrm{CO}$. These could be responsible for the low methanation activity. In addition, a $150 \mathrm{~h}$ stability test under $2 \mathrm{MPa}$ and $300{ }^{\circ} \mathrm{C}$ showed that $5 \mathrm{Co}-\mathrm{Ni} / \mathrm{SiC}$ catalyst was very stable for $\mathrm{CO}$ methanation reaction.
\end{abstract}

Key words: CO Methanation, Ni/SiC Catalysts, Second Metal

\section{Introduction}

Natural gas is a clean fossil fuel that has a higher calorific value compared with petroleum and coal. Due to the exhaustion of natural gas and the wish for a renewable alternative to natural gas, the production of synthetic or substitute natural gas (SNG) from coal or drybiomass has attracted more and more attention [1-3]. As a versatile energy carrier, SNG is inter-changeable with natural gas and therefore can be used as a green alternative fuel in transportation, power stations and heating $[2,4]$. On the other hand, the high conversion efficiency and the already existing gas distribution infrastructure such as pipelines also favor for the development of SNG projects [2,5-8]. It has been reported that a commercial SNG plant called Great Plains Synfuel Plant was commissioned in United States in 1984 and has been producing 4.8 Mio $^{3}$ SNG per day by the coalto-SNG technology [2]. Some institutes, such as the Energy Research Center of the Netherlands, Center for Solar Energy and Hydrogen Research in Stuttgart and Paul-Scherrer Institute in Switzerland, have developed different biomass-to-SNG technologies [2,4]. In China, a number of coal-to-SNG projects have also been proposed: Datang Hexigten SNG Project, Datang Huayin SNG Project, Shanxi SNG Project [2]. All of the plants and institutes produce SNG from coal or dry-biomass by thermo-chemical process, which includes gasifi-

\footnotetext{
${ }^{\dagger}$ To whom correspondence should be addressed.

E-mail: yuyue2890321@163.com or xyguo@sxicc.ac.cn

This is an Open-Access article distributed under the terms of the Creative Commons Attribution Non-Commercial License (http://creativecommons.org/licenses/by$\mathrm{nc} / 3.0$ ) which permits unrestricted non-commercial use, distribution, and reproduction in any medium, provided the original work is properly cited.
}

cation step, gas cleaning/conditioning step and subsequent methanation step. Most researchers focus their attention on the synthesis of methane from carbon monoxide and hydrogen because it is one of the most essential steps in the production of SNG.

It is well known that the noble and transition metal-based catalysts can efficiently catalyze the hydrogenation of carbon monoxide. Although, the supported noble metals such as $\mathrm{Rh}, \mathrm{Ru}, \mathrm{Pd}$ and $\mathrm{Pt}$ show high activity and selectivity toward methane in CO methanation reaction [9-14]. However, the high costs and restricted availabilities greatly limit their applications in industry [15]. Compared with noble metals, nickel-based catalysts have drawn much attention due to their low price and good activity for the methanation reaction [2].

Since the hydrogenation of carbon monoxide toward methane was first reported by Sabatier and Senderens in 1902 [16], the reaction mechanism of $\mathrm{CO}$ methanation reaction has also been investigated intensively. It is widely accepted that the $\mathrm{CO}$ is dissociated into $\mathrm{CH}_{x}$ as intermediate species by assistance of $\mathrm{H}$ after $\mathrm{CO}$ adsorbed on the surface of catalysts and then the $\mathrm{CH}_{x}$ is hydrogenated to produce methane $[17,18]$. Therefore, the introduction of promoters is possible to improve activity of catalysts by enhancing the adsorption amount of $\mathrm{CO}$, by facilitating $\mathrm{CO}$ dissociation or by stabilizing intermediate species. It has been reported that the addition of $\mathrm{La}$ and $\mathrm{Ce}$ could form a new kind of active sites and promote the dissociation of carbon monoxide [19-22]. Some researchers found that the addition of Zr, V, Mo, $\mathrm{W}$ and Re had positive effect for the dissociation of $\mathrm{CO}$ and could enhance the formation of intermediate species on the catalyst surface [23-26]. $\mathrm{Co}, \mathrm{Cu}$ and $\mathrm{Zn}$ were also widely investigated as promoters in the hydrogenation of carbon oxides. It has been reported 
that the activities of Fischer-Tropsch synthesis catalysts could be improved by introducing $\mathrm{Co}$ or $\mathrm{Cu}$ to form bimetallic nanoparticles [27,28]. Zhao et al. [29] reported that the addition of cobalt could increase the activity of $\mathrm{Mn} / \mathrm{SiO}_{2}$ catalyst for $\mathrm{CO}$ hydrogenation and enhance the selectivity toward light hydrocarbons. Hu et al. [21] demonstrated that the addition of $\mathrm{Co}$ into $\mathrm{Ni} / \mathrm{Al}_{2} \mathrm{O}_{3}$ catalyst could promote the methanation reaction. Boellard et al. [30] found that the activity of CO hydrogenation could be enhanced by adding copper to active iron phase. Tsai et al. [15] investigated the $\mathrm{CO}$ hydrogenation reaction on $\mathrm{CoCuZnO}$ catalyst, and found that $\mathrm{Cu}$ could decrease the catalytic activity for $\mathrm{CO}$ hydrogenation while the addition of $\mathrm{Zn}$ could highly disperse active metal components and improve the catalytic activity for hydrocarbon synthesis. Fujitani et al. [31] investigated the effect of $\mathrm{Zn}$ in the promotion of methanol synthesis over $\mathrm{Cu}$ surfaces and found that a kind of special site was formed on the surface of $\mathrm{Zn}$-doped catalyst, which could stabilize intermediate species during $\mathrm{CO}_{2}$ hydrogenation reaction. Lin et al. [32] reported that $\mathrm{Zn}$ could be an electronic promoter to improve the performance of $\mathrm{Cu}-\mathrm{Fe}$ catalyst for $\mathrm{CO}$ hydrogenation.

To resolve the highly exothermic problem of total methanation (methanation reaction with pure syngas as the feedstock [5]), we used $\mathrm{SiC}$ as support and found that the catalysts exhibited high activity and stability due to the excellent thermal stability and high thermal conductivity of the $\mathrm{SiC}$ support [33]. We modified $\mathrm{Ni} / \mathrm{SiC}$ catalyst by a second metal $\mathrm{Co}, \mathrm{Cu}$ or $\mathrm{Zn}$ to study the effect of the second metal on the performance of $\mathrm{Ni} / \mathrm{SiC}$ catalysts for $\mathrm{CO}$ methanation reaction. The results were compared with those of pure $\mathrm{Ni} / \mathrm{SiC}$ catalyst and $\mathrm{Co} / \mathrm{SiC}$ catalyst, and the influences of $\mathrm{Co}, \mathrm{Cu}$ or $\mathrm{Zn}$ on the performance of $\mathrm{Ni} / \mathrm{SiC}$ catalyst were discussed.

\section{Experimental Section}

\section{2-1. Catalyst preparation}

$\mathrm{Ni}\left(\mathrm{NO}_{3}\right)_{2} \cdot 6 \mathrm{H}_{2} \mathrm{O}, \mathrm{Co}\left(\mathrm{NO}_{3}\right)_{2} \cdot 6 \mathrm{H}_{2} \mathrm{O}, \mathrm{Cu}\left(\mathrm{NO}_{3}\right)_{2} \cdot 6 \mathrm{H}_{2} \mathrm{O}$ and $\mathrm{Zn}\left(\mathrm{NO}_{3}\right)_{2} \cdot 6 \mathrm{H}_{2} \mathrm{O}$

were used as metal precursor salts. The $\mathrm{SiC}$ support was prepared by a sol-gel and carbothermal reduction route [34], and the catalyst referred to as $\mathrm{Ni} / \mathrm{SiC}$ was prepared by the conventional impregnation method. $\mathrm{SiC}$ support was added into $\mathrm{Ni}\left(\mathrm{NO}_{3}\right)_{2}$ aqueous solution under stirring, and then the slurry was heated at $80{ }^{\circ} \mathrm{C}$ until nearly all the water was evaporated. After drying at $100{ }^{\circ} \mathrm{C}$ overnight, the sample was calcined in air at $550{ }^{\circ} \mathrm{C}$ for $4 \mathrm{~h}$. The loading of $\mathrm{Ni}$ in the catalysts was $13 \mathrm{wt} \%$ (Elemental $\mathrm{wt} \%$ relative to the weight of the catalyst).

The modified-Ni/SiC catalysts with $\mathrm{Co}, \mathrm{Cu}$ or $\mathrm{Zn}$ were prepared by co-impregnation method. The $\mathrm{SiC}$ support was impregnated in $\mathrm{Ni}\left(\mathrm{NO}_{3}\right)_{2}$ aqueous solution mixed with a suitable amount of $\mathrm{Co}\left(\mathrm{NO}_{3}\right)_{2} \cdot 6 \mathrm{H}_{2} \mathrm{O}$, $\mathrm{Cu}\left(\mathrm{NO}_{3}\right)_{2} \cdot 6 \mathrm{H}_{2} \mathrm{O}$ or $\mathrm{Zn}\left(\mathrm{NO}_{3}\right)_{2} \cdot 6 \mathrm{H}_{2} \mathrm{O}$, and then stirred for $12 \mathrm{~h}$. After heating at $80{ }^{\circ} \mathrm{C}$ to evaporate water, the mixtures were dried at $100{ }^{\circ} \mathrm{C}$ overnight. Finally, the samples were calcined at $550{ }^{\circ} \mathrm{C}$ in air for $4 \mathrm{~h}$. The catalysts are denoted as $x \mathrm{M}-\mathrm{Ni} / \mathrm{SiC}(\mathrm{M}=\mathrm{Co}, \mathrm{Cu}$ and $\mathrm{Zn}$, respectively), where $x$ is the loading of promoters. The loading of $\mathrm{Ni}$ over all these catalysts is $13 \mathrm{wt} \%$.

\section{2-2. Characterization Techniques}

The crystalline phases of the catalysts were analyzed by a Rigaku D-Max/RB X-ray diffractometer (XRD) with $\mathrm{Cu} \mathrm{K} \alpha$ radiation and a scanning rate of $6 \% \mathrm{~min}$. The morphology and structure of the catalysts were analyzed by JEOL-2010 transmission electron microscopy (TEM). X-ray photoelectron spectra (XPS) measurements were performed on a Kratos XSAM800 spectrometer using Al Ka X-ray source. The residual pressure inside the analysis chamber was below $2 \times 10^{-7} \mathrm{~Pa}$. All binding energies were referred to the $\mathrm{C}_{1 \mathrm{~s}}$ line at $284.8 \mathrm{eV}$.

Temperature-programmed reduction of $\mathrm{H}_{2}\left(\mathrm{H}_{2}\right.$-TPR) was carried out in a continuous flow quartz reactor. About $50 \mathrm{mg}$ (40-60 mesh) of the catalysts were packed between two layers of quartz wool in the reactor. Prior to the TPR measurements, the catalysts were pretreated in a following $\mathrm{Ar}$ gas at $500{ }^{\circ} \mathrm{C}$ for $1 \mathrm{~h}$, and then cooled to room temperature in the Ar flow. After that, the temperature of the reactor was increased from room temperature to $900{ }^{\circ} \mathrm{C}$ at a constant rate of $5{ }^{\circ} \mathrm{C} / \mathrm{min}$ and kept at $900{ }^{\circ} \mathrm{C}$ for $20 \mathrm{~min}$ in a $5 \% \mathrm{H}_{2} / \mathrm{Ar}$ mixture gas at a flow rate of $40 \mathrm{~mL} / \mathrm{min}$. The outlet gases were passed through 5A molecular sieve to eliminate water and then were analyzed by a gas chromatograph equipped with thermal conductivity detector.

The temperature programmed desorption of $\mathrm{CO}$ (CO-TPD) measurements were performed in the similar reactor as the above TPR. After being pre-reduced in a $5 \% \mathrm{H}_{2} / \mathrm{Ar}$ mixture gas at $400{ }^{\circ} \mathrm{C}$ for $1.5 \mathrm{~h}$, the samples ( $100 \mathrm{mg}$ with $40-60 \mathrm{mesh}$ ) were purged with Ar at the reduction temperature for $0.5 \mathrm{~h}$, and then cooled to $40{ }^{\circ} \mathrm{C}$ in $\mathrm{Ar}$ flow. Pluses of $\mathrm{CO}$ were injected into the Ar flow through the samples until the adsorption of $\mathrm{CO}$ on the catalyst surface reached to saturation. After purging the samples with $\mathrm{He}$ for $1 \mathrm{~h}$ at $40^{\circ} \mathrm{C}$, the reactor was heated from $40{ }^{\circ} \mathrm{C}$ to $400{ }^{\circ} \mathrm{C}$ at a constant rate of $5{ }^{\circ} \mathrm{C} / \mathrm{min}$ in $\mathrm{He}$ flow with a follow rate of $40 \mathrm{~mL} / \mathrm{min}$. The outlet gases were analyzed by a gas chromatograph.

\section{2-3. Methanation measurement}

The performance of the catalysts was tested in a fixed bed reactor with an inner diameter of $6 \mathrm{~mm}$ using the mixed gases of $\mathrm{H}_{2}$ and $\mathrm{CO}$ (molar ratio of $\mathrm{H}_{2} / \mathrm{CO}=3$, without diluent gas). In a typical experiment, about $0.8 \mathrm{ml}$ of catalyst (40-60 mesh) was placed in the middle of the reactor, and then the mixed gases were fed into the reactor with a space velocity of $4,500 \mathrm{~h}^{-1}$. All catalysts were reduced in situ at $500{ }^{\circ} \mathrm{C}$ in $\mathrm{H}_{2}$ for $2 \mathrm{~h}$ prior to each reaction and all experiments were performed at $2 \mathrm{MPa}$. To achieve steady results, the reaction was kept at each temperature for $1 \mathrm{~h}$. The outlet productions from the reactor were analyzed by GC-14B gas chromatograph with TDX-01 column and a GDX-104 column using thermal conductivity detector and flame ionization detector, respectively. The $\mathrm{CO}$ conversion $\left(\mathrm{X}_{\mathrm{CO}}\right)$ and $\mathrm{CH}_{4}$ selectivity $\left(\mathrm{S}_{\mathrm{CH} 4}\right)$ were estimated by the following equations:

$$
\begin{aligned}
& \mathrm{X}_{C O}(\%)=\left(\mathrm{F}_{C O, \text { in }}-\mathrm{F}_{C O, \text { out }}\right) / \mathrm{F}_{C O, \text { in }} \times 100 \% \\
& \mathrm{~S}_{C H 4}(\%)=\mathrm{F}_{C H, \text { out }} /\left(\mathrm{F}_{C O, \text { in }}-\mathrm{F}_{C O, \text { out }}\right) \times 100 \%
\end{aligned}
$$

Korean Chem. Eng. Res., Vol. 52, No. 5, October, 2014 


\section{Results and Discussion}

\section{3-1. Catalytic performance}

3-1-1. Effect of $\mathrm{Co}, \mathrm{Cu}$ and $\mathrm{Zn}$ on $\mathrm{Ni} / \mathrm{SiC}$ catalytic performance

$\mathrm{CO}$ methanation reaction was investigated over pure $\mathrm{Ni} / \mathrm{SiC}$ and modified $\mathrm{Ni} / \mathrm{SiC}$ catalysts with $\mathrm{Co}, \mathrm{Cu}$ and $\mathrm{Zn}$ under the same reaction conditions. Fig. 1 shows the $\mathrm{CO}$ conversion $\left(\mathrm{X}_{\mathrm{CO}}\right)$ results of the
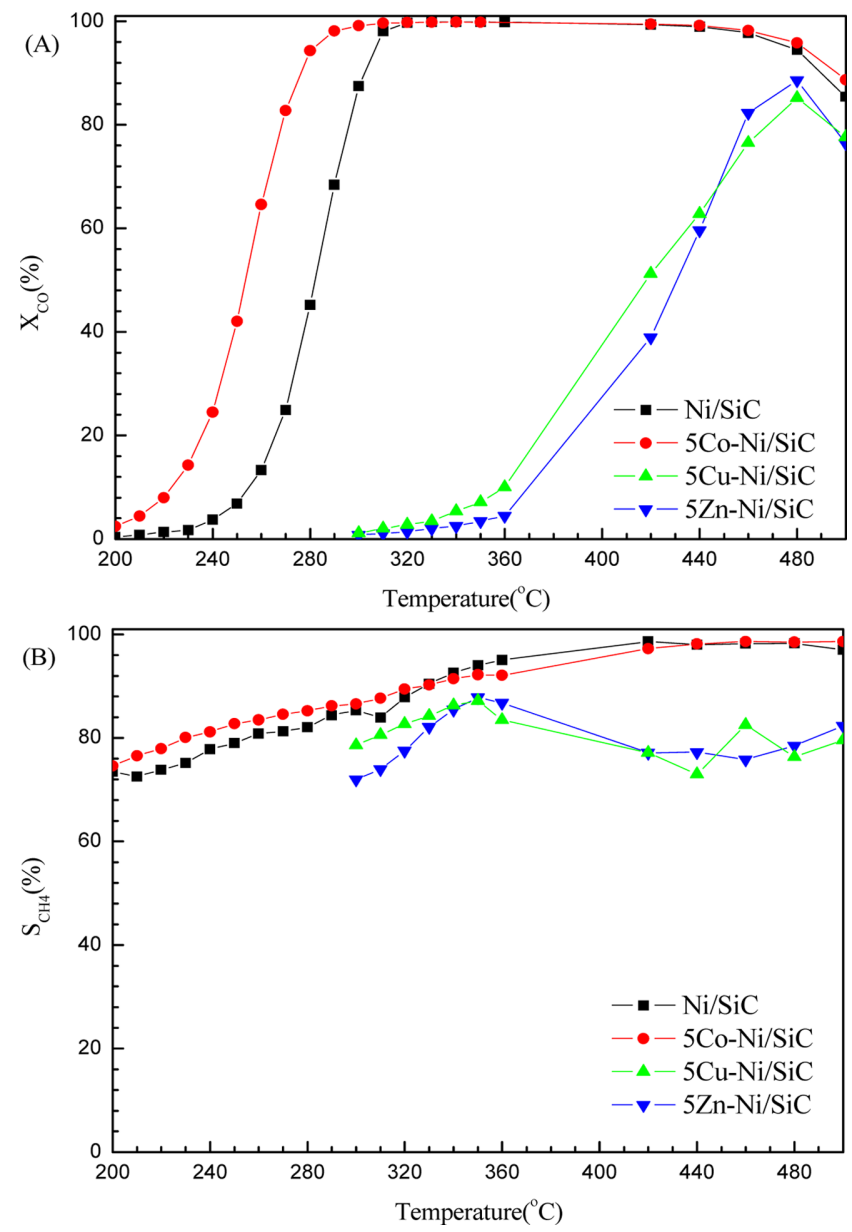

Fig. 1. Influences of $\mathrm{Co}, \mathrm{Cu}$ and $\mathrm{Zn}$ modification on the catalytic performance of $\mathrm{Ni} / \mathrm{SiC}$ catalysts for $\mathrm{CO}$ methanation reaction. (A) Conversions of $\mathrm{CO}\left(\mathrm{X}_{\mathrm{CO}}\right)$, (B) Selectivity of $\mathrm{CH}_{4}\left(\mathrm{~S}_{\mathrm{CH}_{4}}\right)$. Reaction conditions: $\mathrm{P}=2.0 \mathrm{MPa}, \mathrm{H}_{2} / \mathrm{CO}=3, \mathrm{GSV}=4500 \mathrm{~h}^{-1}$. methanation catalysts, which are plotted as functions of reaction temperature. It can be seen that the $\mathrm{CO}$ methanation reaction over $\mathrm{Ni} / \mathrm{SiC}$ and $5 \mathrm{Co}-\mathrm{Ni} / \mathrm{SiC}$ started at $200{ }^{\circ} \mathrm{C}$ and the $\mathrm{X}_{\mathrm{CO}}$ over the two catalysts increased with increasing temperature. From the figure, the $\mathrm{X}_{C O}$ is about $98 \%$ over $5 \mathrm{Co}-\mathrm{Ni} / \mathrm{SiC}$ at $290{ }^{\circ} \mathrm{C}$, while it is only $68 \%$ over $\mathrm{Ni} / \mathrm{SiC}$ at the same condition. For $5 \mathrm{Cu}-\mathrm{Ni} / \mathrm{SiC}$ and $5 \mathrm{Zn}-\mathrm{Ni} / \mathrm{SiC}$, however, no methanation activity was detected until the reaction temperature was over $300{ }^{\circ} \mathrm{C}$. The $\mathrm{X}_{C O}$ over $5 \mathrm{Cu}-\mathrm{Ni} / \mathrm{SiC}$ and $5 \mathrm{Zn}-$ $\mathrm{Ni} / \mathrm{SiC}$ increased with increasing reaction temperature and then achieved a maximum of about $85 \%$ at $480{ }^{\circ} \mathrm{C}$ (Fig. 1A). The turnover frequency (TOF) values of CO defined as moles of carbon monoxide converted per surface metallic atom per second are shown in Table 1. The TOF value for $5 \mathrm{Co}-\mathrm{Ni} / \mathrm{SiC}\left(0.00306 \mathrm{~s}^{-1}\right)$ is more than three times as high as that for $\mathrm{Ni} / \mathrm{SiC}\left(0.00091 \mathrm{~s}^{-1}\right)$ at $220{ }^{\circ} \mathrm{C}$. While for $5 \mathrm{Cu}-\mathrm{Ni} / \mathrm{SiC}$ and $5 \mathrm{Zn}-\mathrm{Ni} / \mathrm{SiC}$, the TOF values are $0.00133 \mathrm{~s}^{-1}$ and $0.00112 \mathrm{~s}^{-1}$, respectively, even at $320^{\circ} \mathrm{C}$. Therefore, the addition of $\mathrm{Co}$ improves the methanation activity, whereas $\mathrm{Cu}$ and $\mathrm{Zn}$ play opposite roles for $\mathrm{CO}$ methanation reaction. Besides that, an obvious decrease of $\mathrm{X}_{C O}$ over the catalysts can be found when the reaction temperature is higher than $480{ }^{\circ} \mathrm{C}$ (Fig. 1A). This behavior can be explained by the thermodynamic limitation of $\mathrm{CO}$ methanation reaction [33]. Because the $\mathrm{CO}$ methanation reaction is a strongly exothermic reaction, too high reaction temperature is not favorable for this reaction.

Fig. 1B shows the results of methane selectivity $\left(\mathrm{S}_{\mathrm{CH} 4}\right)$ over pure $\mathrm{Ni} / \mathrm{SiC}$ and modified $\mathrm{Ni} / \mathrm{SiC}$ catalysts. $\mathrm{S}_{\mathrm{CH} 4}$ over $\mathrm{Ni} / \mathrm{SiC}$ and $5 \mathrm{Co}-$ $\mathrm{Ni} / \mathrm{SiC}$ increases with increasing the reaction temperature and almost achieves a maximum above $440{ }^{\circ} \mathrm{C}$. For $5 \mathrm{Cu}-\mathrm{Ni} / \mathrm{SiC}$ and $5 \mathrm{Zn}-\mathrm{Ni} /$ $\mathrm{SiC}$, however, the $\mathrm{S}_{\mathrm{CH} 4}$ is always lower than $80 \%$ even at high reaction temperature.

Except methane and water, the by-products of CO hydrogenation under present reaction condition are carbon dioxide (water-gas-shift reaction, $\mathrm{CO}+\mathrm{H}_{2} \mathrm{O}=\mathrm{CO}_{2}+\mathrm{H}_{2}$ ) and higher hydrocarbons, e.g., $\mathrm{C}_{2} \mathrm{H}_{6}, \mathrm{C}_{2} \mathrm{H}_{4}, \mathrm{C}_{3} \mathrm{H}_{8}, \mathrm{C}_{3} \mathrm{H}_{6}, \mathrm{MeOH}, \mathrm{EtOH}$. The selectivity of products over pure $\mathrm{Ni} / \mathrm{SiC}$ and modified $\mathrm{Ni} / \mathrm{SiC}$ catalysts at $420{ }^{\circ} \mathrm{C}$ is shown in Table 2 . The addition of $\mathrm{Cu}$ and $\mathrm{Zn}$ clearly increases the by-product selectivity of $\mathrm{CO}$ hydrogenation reaction. Therefore, it is suggested that $\mathrm{Cu}$ and $\mathrm{Zn}$ have a negative effect on $\mathrm{Ni} / \mathrm{SiC}$ catalyst for the methanation reaction in the present conditions.

Table 1. Metallic crystallite size and TOF results of $\mathrm{CO}$ over different methanation catalysts

\begin{tabular}{lccccc}
\hline \hline Catalysts & $\begin{array}{c}\text { Content of promoters } \\
(\mathrm{wt} \%)\end{array}$ & $\begin{array}{c}\text { NiO crystallite size } \\
(\mathrm{nm})^{a}\end{array}$ & $\begin{array}{c}\text { Ni crystallite size } \\
(\mathrm{nm})^{b}\end{array}$ & $\begin{array}{c}\text { NiO crystallite size } \\
(\mathrm{nm})^{c}\end{array}$ & $\begin{array}{c}\text { TOF of CO } \\
\text { at } 220^{\circ} \mathrm{C}\left(\times 10^{4} \mathrm{~s}^{-1}\right)\end{array}$ \\
\hline $\mathrm{Ni} / \mathrm{SiC}$ & - & 20.4 & 21.2 & 23.4 & 9.1 \\
$1 \mathrm{Co}-\mathrm{Ni} / \mathrm{SiC}$ & 1 & 19.1 & 20.1 & 20.4 & 11.4 \\
$3 \mathrm{Co}-\mathrm{Ni} / \mathrm{SiC}$ & 3 & 17.5 & 18.3 & 15.6 & 13.2 \\
$5 \mathrm{Co}-\mathrm{Ni} / \mathrm{SiC}$ & 5 & 15.3 & 16.2 & 12.3 & 30.6 \\
$7 \mathrm{Co}-\mathrm{Ni} / \mathrm{SiC}$ & 7 & 16.3 & 17.4 & 20.3 & 30.9 \\
$5 \mathrm{Cu}-\mathrm{Ni} / \mathrm{SiC}$ & 5 & 19.7 & 20.6 & 22.1 & $13.3 \mathrm{~d}$ \\
$5 \mathrm{Zn}-\mathrm{Ni} / \mathrm{SiC}$ & 5 & 20.0 & 22.7 & 21.9 & $11.2 \mathrm{~d}$ \\
\hline
\end{tabular}

${ }^{a}$ Calculated from $\mathrm{NiO}(012)$ plane by Scherrer's equation from XRD results.

${ }^{b}$ Calculated from Ni (111) plane by Scherrer's equation from XRD results.

${ }^{c}$ Average size $=\Sigma n_{i} d_{i}^{3} / \Sigma n_{i} d_{i}^{2}$ from TEM images.

${ }^{d} \mathrm{TOF}$ results of $\mathrm{CO}$ at $320^{\circ} \mathrm{C}$. 
Table 2. The selectivity of products over catalysts at $420^{\circ} \mathrm{C}$

\begin{tabular}{|c|c|c|c|c|c|}
\hline & $\mathrm{CH}_{4}$ & $\mathrm{C}_{2} \mathrm{H}_{x}$ & $\mathrm{C}_{3} \mathrm{H}_{x}$ & $\mathrm{CO}_{2}$ & $\mathrm{CHO}$ \\
\hline $\mathrm{Ni} / \mathrm{SiC}$ & 0.981087 & 0.000326 & 0.0000329 & 0.018541 & 0.000013 \\
\hline $5 \mathrm{Co}-\mathrm{Ni} / \mathrm{SiC}$ & 0.97546 & 0.005838 & 0.000323 & 0.018308 & 0.000071 \\
\hline $5 \mathrm{Cu}-\mathrm{Ni} / \mathrm{SiC}$ & 0.771266 & 0.027543 & 0.000953 & 0.200238 & 0.001939 \\
\hline $5 \mathrm{Zn}-\mathrm{Ni} / \mathrm{SiC}$ & 0.771372 & 0.037007 & 0.008405 & 0.183216 & 0.001743 \\
\hline
\end{tabular}
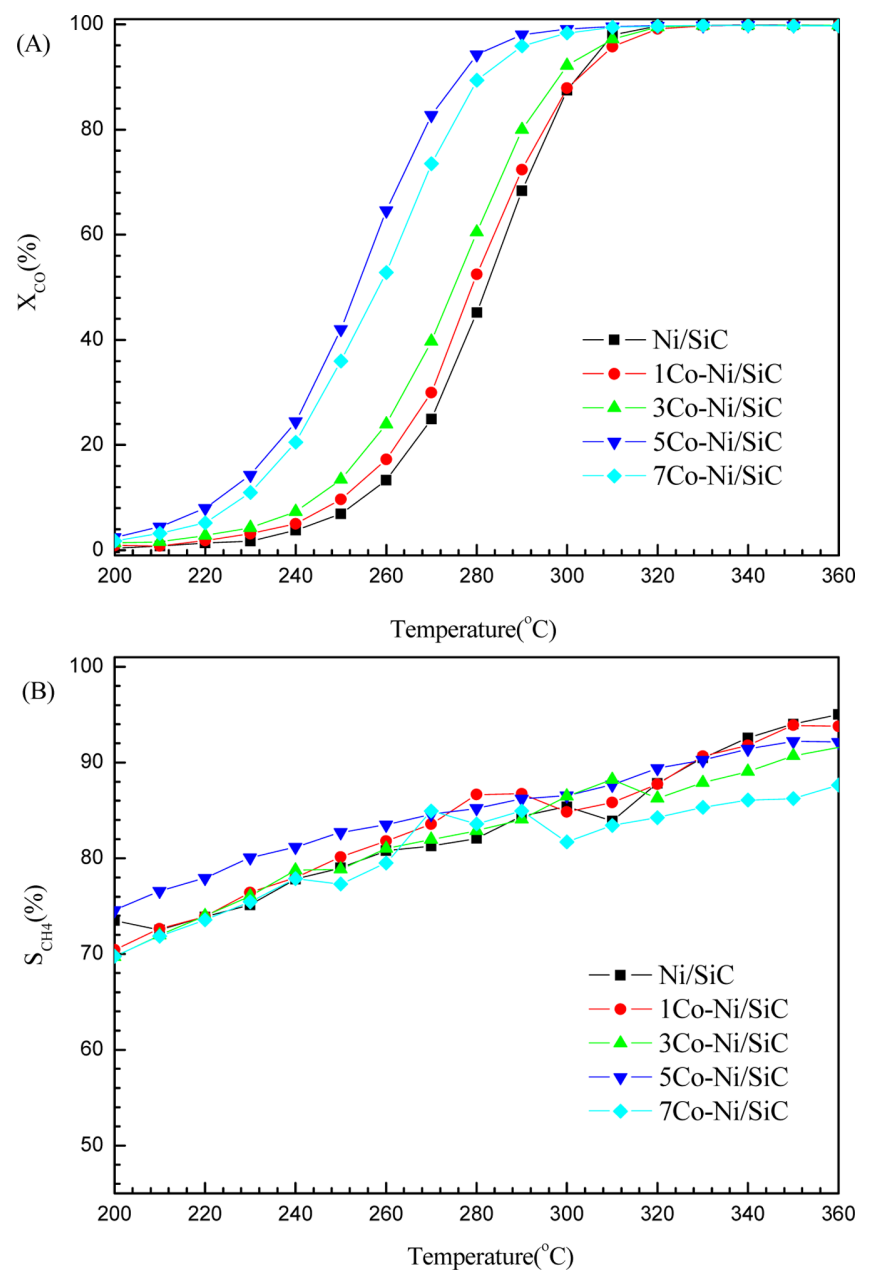

Fig. 2. Catalytic performance of $\mathrm{Ni} / \mathrm{SiC}$ and $\mathrm{Co}$-modified $\mathrm{Ni} / \mathrm{SiC}$ catalysts with different Co loadings. (A) Conversions of $\mathrm{CO}\left(\mathbf{X}_{C O}\right),(\mathrm{B})$ Selectivity of $\mathrm{CH}_{4}\left(\mathrm{~S}_{\mathrm{CH}_{4}}\right)$. Reaction conditions: $\mathrm{P}=2.0 \mathrm{MPa}$, $\mathrm{H}_{2} / \mathrm{CO}=3, \mathrm{GSV}=4500 \mathrm{~h}^{-1}$.

\section{3-1-2. Effect of Co loading on methanation activity}

To further study the influence of Co loading on the catalytic activity, we investigated Co-modified $\mathrm{Ni} / \mathrm{SiC}$ catalysts with different $\mathrm{Co}$ contents (1-7 wt $\%)$ for $\mathrm{CO}$ methanation, and the results are shown in Fig. 2. The methanation activity is improved significantly when the $\mathrm{Ni} / \mathrm{SiC}$ catalyst is modified with $\mathrm{Co}$. In addition, Fig. 2 shows that the $\mathrm{CO}$ conversion curve is progressively shifted toward lower reaction temperature with increasing the loading of Co from $1 \mathrm{wt} \%$ to 5 $\mathrm{wt} \%$, and $5 \mathrm{Co}-\mathrm{Ni} / \mathrm{SiC}$ shows a similar $\mathrm{S}_{\mathrm{CH} 4}$ with that of pure $\mathrm{Ni} / \mathrm{SiC}$ catalyst. However, when the loading of $\mathrm{Co}$ is further increased to $7 \mathrm{wt} \%$, the methanation activity shows a little decrease. The results obtained from Table 1 show that the addition of Co can promote the TOF value of $\mathrm{CO}$ at $220^{\circ} \mathrm{C}$, and the TOF can significantly increase with increasing

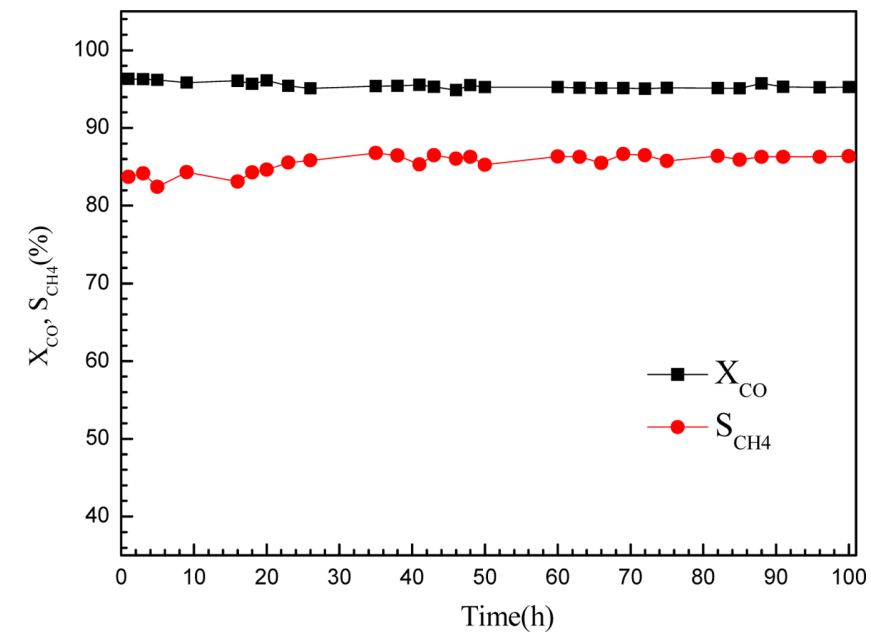

Fig. 3. Long-term stability test of $5 \mathrm{Co}-\mathrm{Ni} / \mathrm{SiC}$ catalyst. Reaction conditions: $\mathrm{T}=280^{\circ} \mathrm{C} ; \mathrm{P}=2.0 \mathrm{MPa} ; \mathrm{H}_{2} / \mathrm{CO}=3 ; \mathrm{GSV}=4500 \mathrm{~h}^{-1}$.

Co loading to $5 \mathrm{wt} \%$. For $7 \mathrm{Co}-\mathrm{Ni} / \mathrm{SiC}$, however, there is no remarkable increase of the TOF value compared with $5 \mathrm{Co}-\mathrm{Ni} / \mathrm{SiC}$. Therefore, 5 $\mathrm{wt} \%$ is a suitable loading of $\mathrm{Co}$ for modifying the $\mathrm{Ni} / \mathrm{SiC}$ catalyst.

\section{3-1-3. Long-term stability test}

Since $5 \mathrm{Co}-\mathrm{Ni} / \mathrm{SiC}$ shows the best performance for methanation reaction, a long-term stability test of $5 \mathrm{Co}-\mathrm{Ni} / \mathrm{SiC}$ was performed under $2 \mathrm{MPa}$ with $\mathrm{H}_{2} / \mathrm{CO}=3$. The reaction temperature was $280^{\circ} \mathrm{C}$ and the space velocity was $4500 \mathrm{~h}^{-1}$. The results are shown in Fig. 3, where $\mathrm{X}_{\mathrm{CO}}$ and $\mathrm{S}_{\mathrm{CH} 4}$ are plotted as the function of time-on-stream. $\mathrm{X}_{\mathrm{CO}}$ and the $\mathrm{S}_{\mathrm{CH} 4}$ are kept at about $95 \%$ and $85 \%$ for $100 \mathrm{~h}$, respectively, indicating that $5 \mathrm{Co}-\mathrm{Ni} / \mathrm{SiC}$ is very stable in the $\mathrm{CO}$ methanation reaction.

\section{3-2. Catalyst characterization}

\section{3-2.1. XRD}

Fig. 4A shows the XRD results of fresh $\mathrm{Ni} / \mathrm{SiC}$ and modified $\mathrm{Ni} /$ $\mathrm{SiC}$ catalysts with $\mathrm{Co}, \mathrm{Cu}$ and $\mathrm{Zn}$. It is demonstrated that the addition species have been highly dispersed on the $\mathrm{SiC}$ surface since no diffraction peaks of $\mathrm{Co}, \mathrm{Cu}$ and $\mathrm{Zn}$ species can be found from the $\mathrm{XRD}$ patterns of catalysts. The average crystallite sizes of $\mathrm{NiO}$ particles calculated from $\mathrm{NiO}(012)$ plane by Scherrer's equation [35] are listed in Table 1. The particle sizes of $\mathrm{NiO}$ over $5 \mathrm{Cu}-\mathrm{Ni} / \mathrm{SiC}$ and $5 \mathrm{Zn}-\mathrm{Ni} / \mathrm{SiC}$ are $19.7 \mathrm{~nm}$ and $20.0 \mathrm{~nm}$, respectively, almost the same as that over $\mathrm{Ni} / \mathrm{SiC}(20.4 \mathrm{~nm})$. For $5 \mathrm{Co}-\mathrm{Ni} / \mathrm{SiC}$, however, the $\mathrm{NiO}$ particle size is about $15.3 \mathrm{~nm}$. Fig. 4B shows the $\mathrm{XRD}$ results of used $\mathrm{Ni} / \mathrm{SiC}$ catalysts modified with or without second metals. The diffraction peaks at $2 \theta=44.3^{\circ}$ and $51.7^{\circ}$ over the used catalysts are 

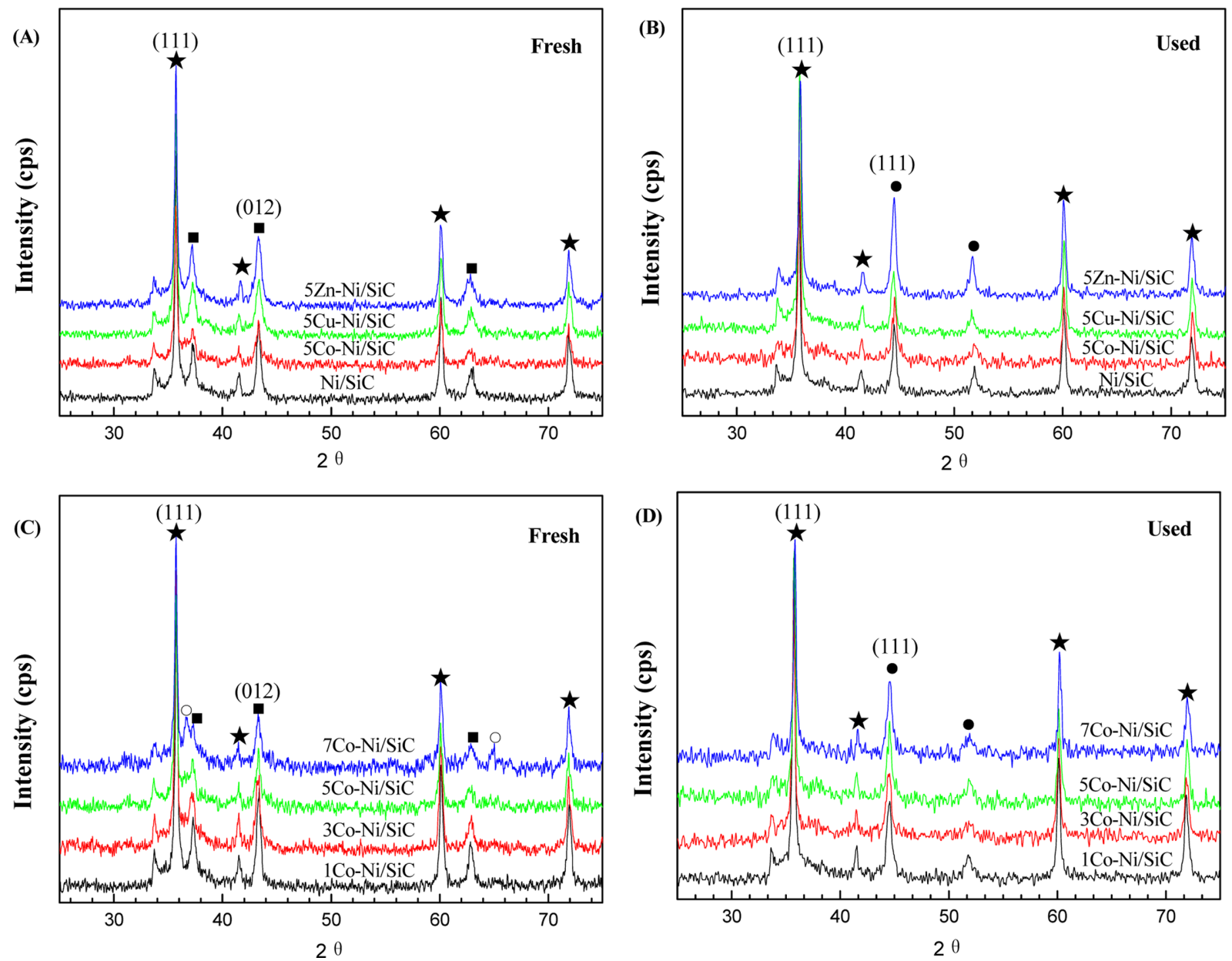

Fig. 4. XRD patterns of fresh and used pure $\mathrm{Ni} / \mathrm{SiC}$ and modified Ni/SiC catalysts. ( $\star$ ) $\mathrm{SiC} ;(\square) \mathrm{NiO} ;(\bigcirc) \mathrm{Ni} ;\left(\mathrm{O}_{)} \mathrm{Co}_{3} \mathrm{O}_{4}\right.$.

attributed to $\mathrm{Ni}$, indicating the metallic nickel is the active phase for CO methanation reaction. From Table 1, interestingly, there is only a slight increment in the size of metallic nickel particles over the used catalysts. This suggests that no serious sintering occurred during the methanation reaction due to the excellent thermostability and heat conductivity of $\mathrm{SiC}$ support. Compared with $\mathrm{Ni} / \mathrm{SiC}, 5 \mathrm{Cu}-\mathrm{Ni} / \mathrm{SiC}$ and $5 \mathrm{Zn}-\mathrm{Ni} / \mathrm{SiC}$, metallic nickel particle on $5 \mathrm{Co}-\mathrm{Ni} / \mathrm{SiC}$ has a smaller size. Therefore, the addition of Co can enhance the dispersion of active metal. This is in accordance with the results reported by Zhang et al. [36], who found that the addition of Co increased the metallic surface and improved the metal dispersion, and thus resulted in a higher activity.

Fig. 4C and Fig. 4D show the XRD results of Co-modified Ni/SiC catalysts with the Co loading from $1 \mathrm{wt} \%$ to $7 \mathrm{wt} \%$ before and after methanation reaction, respectively. The loading of Co influences the intensities of $\mathrm{NiO}$ and metallic Ni diffraction peaks. The average particle sizes of $\mathrm{NiO}$ and metallic $\mathrm{Ni}$ are shown in Table 1. Table 1 shows that the metal particles over fresh and used Co-modified Ni/ $\mathrm{SiC}$ catalysts are smaller than that over $\mathrm{Ni} / \mathrm{SiC}$. With increasing the loading of Co from $1 \mathrm{wt} \%$ to $5 \mathrm{wt} \%$, the average particle sizes of $\mathrm{NiO}$ and Ni over fresh and used catalysts decrease from $19.1 \mathrm{~nm}$ and $20.1 \mathrm{~nm}$ to $15.3 \mathrm{~nm}$ and $16.2 \mathrm{~nm}$, respectively. When further increasing Co loading, the particle size does not decrease. Therefore, $5 \mathrm{wt} \%$ is the suitable loading of $\mathrm{Co}$ for the dispersion of $\mathrm{Ni}$ species over catalysts. In addition, a new diffraction peak attributed to $\mathrm{Co}_{3} \mathrm{O}_{4}$ is interestingly detected over the $7 \mathrm{Co}-\mathrm{Ni} / \mathrm{SiC}$ (Fig. $4 \mathrm{C}$ ), indicating that the Co species are not well dispersed and aggregate on the surface of catalyst in this case. This may result in the decrease of the amount of active sites and be responsible for the decreased activity of $7 \mathrm{Co}-\mathrm{Ni} / \mathrm{SiC}$.

\section{3-2.2. TEM}

The average particle sizes of the methanation catalysts obtained from the TEM images are listed in Table 1, where the particle sizes are in good agreement with the crystallite sizes calculated from the XRD analysis.

Fig. 5 shows TEM results of the morphology and size distribution of metallic particles over pure and modified $\mathrm{Ni} / \mathrm{SiC}$ catalysts before the methanation reaction. It is obvious that $\mathrm{Ni} / \mathrm{SiC}$ has a wide size distribution ranging from 11 to $35 \mathrm{~nm}$, and the percentage of large particles (larger than $25 \mathrm{~nm}$ ) is about $19 \% .5 \mathrm{Cu}-\mathrm{Ni} / \mathrm{SiC}$ and $5 \mathrm{Zn}-\mathrm{Ni} /$ $\mathrm{SiC}$ have similar particle distribution with that of $\mathrm{Ni} / \mathrm{SiC}$. The percentage of large particles reaches about $18 \%$ and $15 \%$ for $5 \mathrm{Cu}-\mathrm{Ni}$ / $\mathrm{SiC}$ and $5 \mathrm{Zn}-\mathrm{Ni} / \mathrm{SiC}$, respectively. For $5 \mathrm{Co}-\mathrm{Ni} / \mathrm{SiC}$, large metal particles are seldom detected and the portion of metal particles between 5 and $15 \mathrm{~nm}$ increases to about $86 \%$. The relatively concentrated dis- 

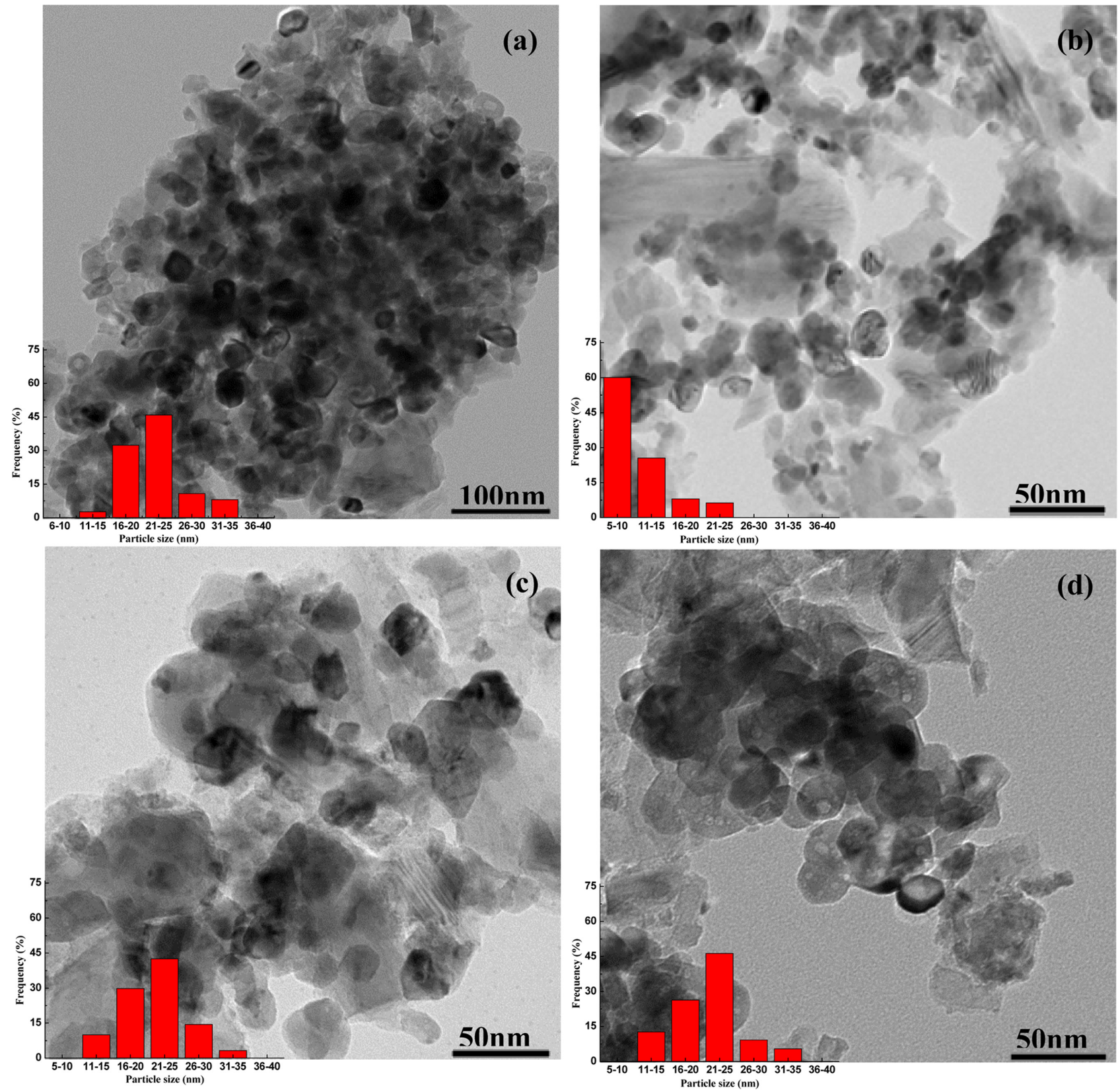

Fig. 5. TEM images and metal particle size distributions of the fresh catalysts. (a) $\mathrm{Ni} / \mathrm{SiC}$; (b) $5 \mathrm{Co}-\mathrm{Ni} / \mathrm{SiC} ;($ c) $5 \mathrm{Cu}-\mathrm{Ni} / \mathrm{SiC}$ and (d) $5 \mathrm{Zn}-\mathrm{Ni} / \mathrm{SiC}$.

tribution of small metal particles further indicates that the active metal is highly dispersed over $5 \mathrm{Co}-\mathrm{Ni} / \mathrm{SiC}$.

\section{3-2.3. XPS}

The relative atom ratios of $\mathrm{Ni}$ to $\mathrm{Si}$ on the used catalysts obtained from XPS analysis are given in Table 3. The $\mathrm{Ni} / \mathrm{Si}$ atom ratio is 0.11 for $\mathrm{Ni} / \mathrm{SiC}$ and 0.15 for $5 \mathrm{Co}-\mathrm{Ni} / \mathrm{SiC}$, respectively. Obviously, the latter has a higher $\mathrm{Ni} / \mathrm{Si}$ ratio. This illustrates that the introduction of $\mathrm{Co}$ enriches $\mathrm{Ni}$ species on the surface of catalyst, which results in the increase of active sites over $5 \mathrm{Co}-\mathrm{Ni} / \mathrm{SiC}$. For $5 \mathrm{Cu}-\mathrm{Ni} / \mathrm{SiC}$ and $5 \mathrm{Zn}$ $\mathrm{Ni} / \mathrm{SiC}$, the $\mathrm{Ni} / \mathrm{Si}$ atom ratio is 0.09 and 0.07 , respectively, which are lower than that of $\mathrm{Ni} / \mathrm{SiC}$. Since there is no significant increase of the metal particle sizes over $5 \mathrm{Cu}-\mathrm{Ni} / \mathrm{SiC}$ and $5 \mathrm{Zn}-\mathrm{Ni} / \mathrm{SiC}$ (according to the $\mathrm{XRD}$ and TEM results), the lower $\mathrm{Ni} / \mathrm{Si}$ atom ratio is most likely because the nickel particles on $5 \mathrm{Cu}-\mathrm{Ni} / \mathrm{SiC}$ and $5 \mathrm{Zn}-\mathrm{Ni} / \mathrm{SiC}$ are partially covered by $\mathrm{Cu}$ or $\mathrm{Zn}$ species, resulting in the decrease of active sites over catalysts.

Fig. 6 shows the XPS results of Ni $2 \mathrm{p}_{3 / 2}$ for the used catalysts. The peak at about $853.0 \mathrm{eV}$ should belong to the metallic Ni state [37]. Compared with $\mathrm{Ni} / \mathrm{SiC}, 5 \mathrm{Co}-\mathrm{Ni} / \mathrm{SiC}$ shows a visible negative shift of $\mathrm{Ni} 2 \mathrm{p}_{3 / 2}$ binding energy, suggesting that the electron density on $\mathrm{Ni}$ increases. This may be due to the transfer of electrons from cobalt species to nickel species [36-39]. For used $5 \mathrm{Cu}-\mathrm{Ni} / \mathrm{SiC}$ and $5 \mathrm{Zn}-\mathrm{Ni} / \mathrm{SiC}$, however, the shift of $\mathrm{Ni} 2 \mathrm{p}_{3 / 2}$ binding energy is not detected. Therefore, the addition of $\mathrm{Cu}$ and $\mathrm{Zn}$ does not influence the electron environment of $\mathrm{Ni}$ species. As reported in earlier literature, the dissociation 


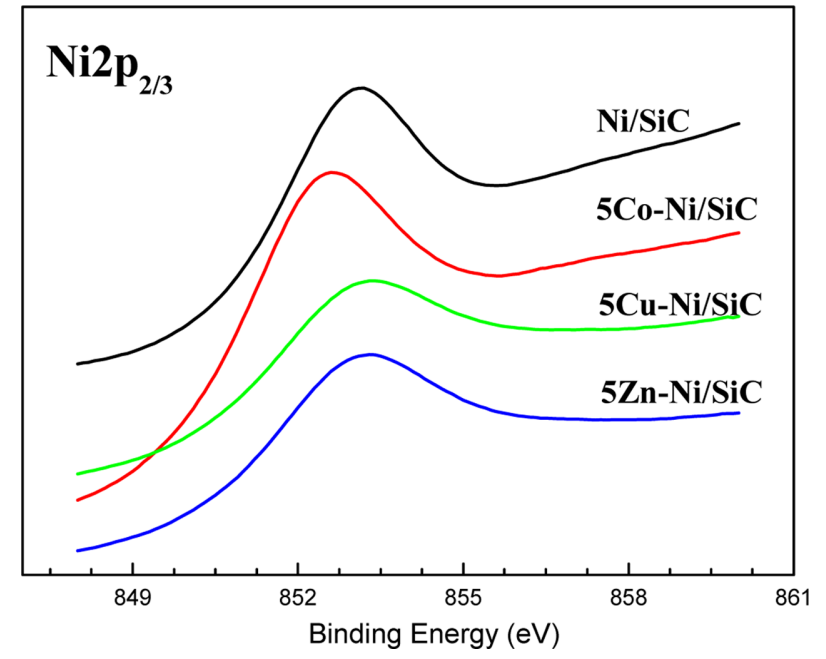

Fig. 6. XPS spectra of $\mathrm{Ni}_{2} \mathrm{p}_{3 / 2}$ over the used methanation catalysts.

of $\mathrm{C}-\mathrm{O}$ bond in adsorbed $\mathrm{CO}$ species is the rate-determining step in the $\mathrm{CO}$ methanation reaction $[17,40]$. When $\mathrm{CO}$ is adsorbed on the metal particles [41], a d- $\pi$ feedback is formed by means of donation of the d-electron of nickel atoms to the vacant anti-bonding $\pi^{*}$ orbit of carbon monoxide molecule [20]. For $5 \mathrm{Co}-\mathrm{Ni} / \mathrm{SiC}$, the d-electron density of the surface $\mathrm{Ni}$ atoms is increased by the effect of Co species, which can improve the proportion of $d-\pi$ feedback bond and enhance the electron-feedback capacity of the metal to adsorbed $\mathrm{CO}$. As a result, the Ni-C bond becomes stronger and then the $\mathrm{C}-\mathrm{O}$ bond is more easily cleaved, making $\mathrm{CO}$ be activated more easily. Therefore, the introduction of Co improves the methanation activity of $\mathrm{Ni} /$ $\mathrm{SiC}$ catalyst.

\section{3-2.4. CO-TPD}

CO-TPD was carried out to study the effect of $\mathrm{Co}, \mathrm{Cu}$ and $\mathrm{Zn}$ on the behavior of $\mathrm{CO}$ adsorption over the methanation catalysts, and the results are shown in Fig. 7. From the TPD profile of Ni/SiC, there are three desorption peaks $(\alpha, \beta, \gamma)$ at $62{ }^{\circ} \mathrm{C}, 157{ }^{\circ} \mathrm{C}$ and $344{ }^{\circ} \mathrm{C}$, respectively. Peak $\alpha$ is generally assigned to the physical adsorption of $\mathrm{CO}$. Peak $\beta$ can be attributed to desorption of weakly chemisorbed $\mathrm{CO}$. Since the $\mathrm{CO}$ methanation reaction occurred at a temperature lower than $200{ }^{\circ} \mathrm{C}$ over $\mathrm{Ni} / \mathrm{SiC}$ (Fig. 2A), this kind of adsorption may play a role for $\mathrm{CO}$ activation of $\mathrm{CO}$. Peak $\gamma$ is probably attributed to desorption of $\mathrm{CO}$ which has a strong chemical interaction with metal nickel. This kind of adsorbed $\mathrm{CO}$ may be more active because $\mathrm{CO}$ can be completely converted at a temperature around $340{ }^{\circ} \mathrm{C}$. For the

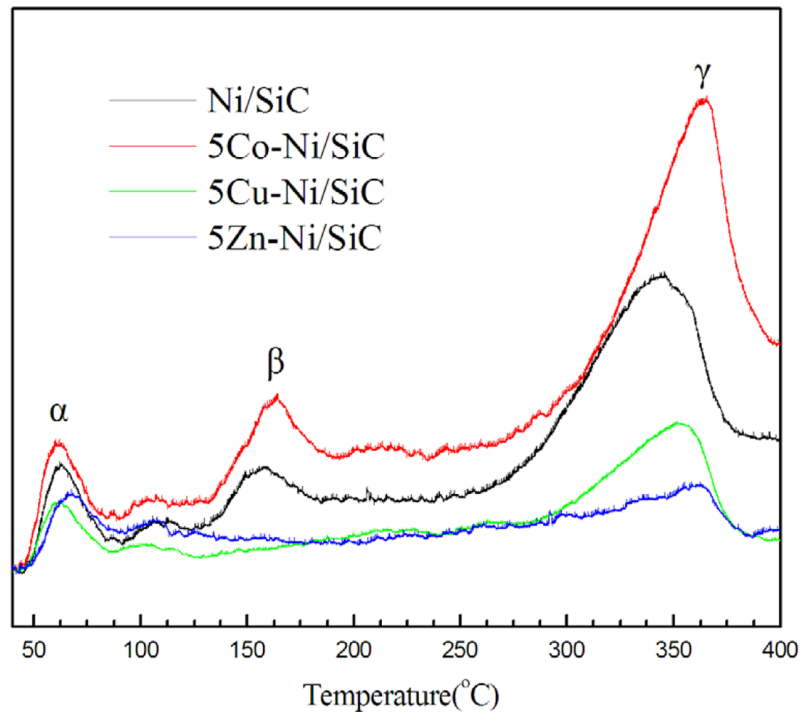

Fig. 7. CO-TPD profiles of pure $\mathrm{Ni} / \mathrm{SiC}$ and $\mathrm{Co}-$, $\mathrm{Cu}$-, or $\mathrm{Zn}$-modified $\mathrm{Ni} / \mathrm{SiC}$ catalysts.

$5 \mathrm{Co}-\mathrm{Ni} / \mathrm{SiC}$, the CO-TPD profile is similar to that of $\mathrm{Ni} / \mathrm{SiC}$, in which three $\mathrm{CO}$ desorption peaks appear. Peaks $\beta$ and $\gamma$ in $5 \mathrm{Co}-\mathrm{Ni} /$ $\mathrm{SiC}$ are shifted to higher temperature, compared with those of $\mathrm{Ni} /$ $\mathrm{SiC}$, indicating that the introduction of Co species can enhance the interaction between adsorbed $\mathrm{CO}$ and active metal. The results obtained from volumetric $\mathrm{CO}$ desorption are shown in Table 3. The total amount of desorbed $\mathrm{CO}$ from $5 \mathrm{Co}-\mathrm{Ni} / \mathrm{SiC}$ is more than that from $\mathrm{Ni} / \mathrm{SiC}$, indicating that the addition of Co species increases the chemisorption amount of $\mathrm{CO}$. On one hand, the introduction of $\mathrm{Co}$ enhances metal dispersion and thus results in the increase of active sites. On the other hand, the special interaction between $\mathrm{Ni}$ and $\mathrm{Co}$ produces a new kind of active site for $\mathrm{CO}$ adsorption. For $5 \mathrm{Cu}-\mathrm{Ni}$ / $\mathrm{SiC}$ and $5 \mathrm{Zn}-\mathrm{Ni} / \mathrm{SiC}$, except the physical adsorption of $\mathrm{CO}$, only one desorption peak ranging from about $290{ }^{\circ} \mathrm{C}$ to $380{ }^{\circ} \mathrm{C}$ is detected. This indicates that only one type of chemisorbed $\mathrm{CO}$ exists on the surface of $5 \mathrm{Cu}-\mathrm{Ni} / \mathrm{SiC}$ and $5 \mathrm{Zn}-\mathrm{Ni} / \mathrm{SiC}$. This type of $\mathrm{CO}$ can produce methane by reacting with $\mathrm{H}_{2}$, since both $5 \mathrm{Cu}-\mathrm{Ni} / \mathrm{SiC}$ and $5 \mathrm{Zn}-\mathrm{Ni}$ / $\mathrm{SiC}$ show methanation activity until the temperature is higher than $300^{\circ} \mathrm{C}$ (Fig. 2A). In addition, from Table 3, the amounts of the chemisorption of $\mathrm{CO}($ peak $\gamma)$ over both $5 \mathrm{Cu}-\mathrm{Ni} / \mathrm{SiC}$ and $5 \mathrm{Zn}-\mathrm{Ni} / \mathrm{SiC}$ are lower than that over $\mathrm{Ni} / \mathrm{SiC}$. This is likely due to the partial coverage of $\mathrm{Ni}$ by $\mathrm{Cu}$ and $\mathrm{Zn}$ species, which results in a decrease of active sites over $5 \mathrm{Cu}-\mathrm{Ni} / \mathrm{SiC}$ and $5 \mathrm{Zn}-\mathrm{Ni} / \mathrm{SiC}$. Similar results were reported by Mo et al. [19], who studied the role of promoters on $\mathrm{Rh} / \mathrm{SiO}_{2}$ catalyst in $\mathrm{CO}$

Table 3. Surface atom ratio of $\mathrm{Ni} / \mathrm{Si}$ and $\mathrm{CO}-\mathrm{TPD}$ results over $\mathrm{Ni} / \mathrm{SiC}$ and $\mathrm{Co}-$, $\mathrm{Cu}$ - or $\mathrm{Zn}$-modified $\mathrm{Ni} / \mathrm{SiC}$ catalysts

\begin{tabular}{|c|c|c|c|c|c|c|c|}
\hline \multirow{2}{*}{ Catalysts } & \multirow{2}{*}{$\begin{array}{l}\text { Surface atom ratio } \\
(\mathrm{Ni} / \mathrm{Si})^{a}\end{array}$} & \multicolumn{3}{|c|}{ Desorption temperature $\left({ }^{\circ} \mathrm{C}\right)$} & \multicolumn{3}{|c|}{ CO uptake $(\mu \mathrm{mol} / \mathrm{g})$} \\
\hline & & $\alpha$ & $\beta$ & $\gamma$ & $\alpha$ & $\beta$ & $\gamma$ \\
\hline $\mathrm{Ni} / \mathrm{SiC}$ & 0.11 & 62 & 157 & 344 & 13.95 & 9.26 & 79.92 \\
\hline $5 \mathrm{Co}-\mathrm{Ni} / \mathrm{SiC}$ & 0.15 & 61 & 164 & 363 & 17.58 & 12.93 & 88.63 \\
\hline $5 \mathrm{Cu}-\mathrm{Ni} / \mathrm{SiC}$ & 0.09 & 61 & - & 354 & 9.96 & - & 39.83 \\
\hline $5 \mathrm{Zn}-\mathrm{Ni} / \mathrm{SiC}$ & 0.07 & 67 & - & 361 & 9.18 & - & 20.17 \\
\hline
\end{tabular}

${ }^{a}$ Obtained from XPS results. 


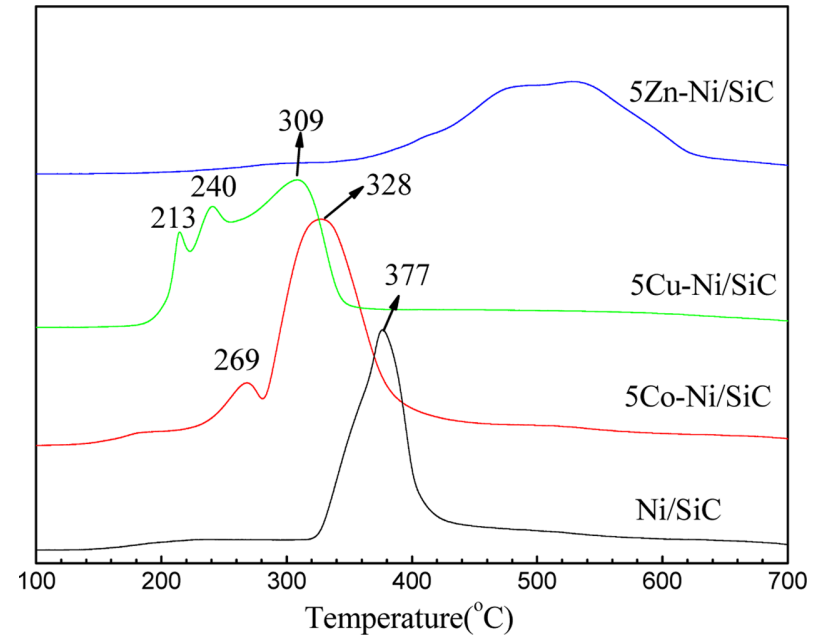

Fig. 8. TPR profiles of pure $\mathrm{Ni} / \mathrm{SiC}$ and $\mathrm{Co}-$, $\mathrm{Cu}-$, or $\mathrm{Zn}$-modified $\mathrm{Ni} /$ $\mathrm{SiC}$ catalysts.

hydrogenation reaction using DRIFTS and found that the addition of $\mathrm{Cu}$ and $\mathrm{Zn}$ suppressed the adsorption of $\mathrm{CO}$ on the catalyst significantly. They also investigated the activity of $\mathrm{Co} / \mathrm{CuZnO}$ catalyst for $\mathrm{CO}$ hydrogenation and found that $\mathrm{ZnO}$ and $\mathrm{Cu}$ could cover/block a substantial number of active sites on $\mathrm{Co}$ [42].

\section{3-2.5. $\mathrm{H}_{2}-\mathrm{TPR}$}

$\mathrm{H}_{2}$-TPR was employed to understand the reduction behavior of the methanation catalysts. Fig. 8 shows the TPR results of $\mathrm{Ni} / \mathrm{SiC}$ and modified $\mathrm{Ni} / \mathrm{SiC}$ catalysts. For $\mathrm{Ni} / \mathrm{SiC}$, only one reduction peak at about $377^{\circ} \mathrm{C}$ is detected, indicating that $\mathrm{NiO}$ is reduced to metallic $\mathrm{Ni}$. Compared with $\mathrm{Ni} / \mathrm{SiC}, 5 \mathrm{Co}-\mathrm{Ni} / \mathrm{SiC}$ shows a lower reduction temperature at about $328^{\circ} \mathrm{C}$, indicating the addition of Co enhances the reducibility of $\mathrm{Ni} / \mathrm{SiC}$ catalyst. This may be due to the interaction between $\mathrm{Co}$ and $\mathrm{Ni}$ species, which decreases the interaction between metal and $\mathrm{SiC}$ support [43-45]. In addition, a shoulder peak at about $269^{\circ} \mathrm{C}$ is detected in the TPR profile of $5 \mathrm{Co}-\mathrm{Ni} / \mathrm{SiC}$. In our earlier work, we found the reduction temperature of $\mathrm{Co} / \mathrm{SiC}$ was about $353{ }^{\circ} \mathrm{C}$ [43]. Thus, it is difficult to discriminate the reduction of cobalt oxide from nickel oxide obviously. In the above XRD and XPS discussion, it was found that the introduction of Co species could enrich the $\mathrm{Ni}$ species on the surface of catalyst. Hence, the shoulder peak should be attributed to the reduction of surface $\mathrm{NiO}[43,46]$.

For $5 \mathrm{Cu}-\mathrm{Ni} / \mathrm{SiC}$, three reduction peaks are detected. The two peaks at about $213{ }^{\circ} \mathrm{C}$ and $240{ }^{\circ} \mathrm{C}$ can be assigned to the reduction of different $\mathrm{CuO}$ species $[47,48]$, and the reduction peak at $309^{\circ} \mathrm{C}$ can be assigned to the reduction of $\mathrm{NiO}$. The lower reduction temperature of $\mathrm{NiO}$ can be understood as follows. The reduced copper is able to activate and dissociate hydrogen, which can spill-over to, and subsequently reduce, the adjacent nickel oxide crystallite [49]. A similar result was also reported in the TPR experiment on $\mathrm{Cu}-\mathrm{Ni} / \mathrm{ZrO}_{2}$ catalyst by Hernández et al. [47], who found that the presence of $\mathrm{Cu}$ facilitated the reduction of $\mathrm{NiO}$. One point should be drawn here that although the addition of $\mathrm{Cu}$ species can decrease the reduction tem- perature of $\mathrm{NiO}$, the methanation activity of $5 \mathrm{Cu}-\mathrm{Ni} / \mathrm{SiC}$ is not improved. This indicates the partial coverage of $\mathrm{Ni}$ by $\mathrm{Cu}$, which decreases the amount of active sites, may be responsible for the decrease of the methanation activity for $5 \mathrm{Cu}-\mathrm{Ni} / \mathrm{SiC}$. For $5 \mathrm{Zn}-\mathrm{Ni} / \mathrm{SiC}$, on the contrary, it shows a wide reduction profile (starts at $380{ }^{\circ} \mathrm{C}$ and ends at $640^{\circ} \mathrm{C}$ ), which is much higher than that of $\mathrm{Ni} / \mathrm{SiC}$. This is agreement with the results reported by Zhu et al. [46], who found that the reduction temperature of $\mathrm{Zn}-\mathrm{Ni} / \mathrm{SiO}_{2}$ catalyst was about $100{ }^{\circ} \mathrm{C}$ higher than that of $\mathrm{Ni} / \mathrm{SiO}_{2}$ catalyst. Chen et al. [50] also reported that the introduction of $\mathrm{Zn}$ could make reduction peak of $\mathrm{Ni} / \mathrm{Al}_{2} \mathrm{O}_{3}$ catalyst shift to higher temperature. The higher reduction temperature of $5 \mathrm{Zn}-\mathrm{Ni}$ / $\mathrm{SiC}$ suggests that the addition of $\mathrm{Zn}$ can increase the interaction between metal and support, and then decrease the reducibility of $\mathrm{Ni}$ / $\mathrm{SiC}$ catalyst.

\section{Conclusion}

Pure Ni/SiC and Co-, $\mathrm{Cu}$ - or $\mathrm{Zn}$-modified $\mathrm{Ni} / \mathrm{SiC}$ catalysts for $\mathrm{CO}$ methanation were prepared by conventional co-impregnation method. The Co-modified Ni/SiC exhibited higher catalytic activity and good selectivity towards $\mathrm{CH}_{4}$. On the contrary, the addition of $\mathrm{Cu}$ and $\mathrm{Zn}$ could dramatically reduce the activity of $\mathrm{Ni} / \mathrm{SiC}$. In addition, a longterm stability test under $2 \mathrm{MPa}$ and $280{ }^{\circ} \mathrm{C}$ showed that $5 \mathrm{Co}-\mathrm{Ni} / \mathrm{SiC}$ was very stable for $\mathrm{CO}$ methanation reaction.

To study the influence of $\mathrm{Co}, \mathrm{Cu}$ and $\mathrm{Zn}$ on the catalytic performance of $\mathrm{Ni} / \mathrm{SiC}$ for $\mathrm{CO}$ methanation reaction, XRD, TEM, XPS, CO-TPD and $\mathrm{H}_{2}$-TPR characterizations were performed. The conclusions are as follows.

(1) The introduction of Co species could decrease the nickel crystallite size and enhance the dispersion of active nickel components, whereas the addition of $\mathrm{Cu}$ and $\mathrm{Zn}$ could cover partial nickel particles, resulting in a decrease of the active sites on the catalyst surface.

(2) The addition of Co could promote the chemisorption of $\mathrm{CO}$, while the introduction of $\mathrm{Cu}$ and $\mathrm{Zn}$ could decrease the chemisorption amount of $\mathrm{CO}$ on the catalysts.

(3) There might be a special interaction between $\mathrm{Co}$ and $\mathrm{Ni}$ in $5 \mathrm{Co}-\mathrm{Ni} / \mathrm{SiC}$ and the electron density on nickel is increased. This could enhance the interaction between $\mathrm{Ni}$ and $\mathrm{CO}$ and promote the dissociation of adsorbed CO.

\section{Acknowledgments}

The work was financially supported by NSFC (Ref. 20973190), the in-house research project of SKLCC (Ref. SKLCC-2008BWZ010), and the National Basic Research Program (Ref. 2011CB201405).

\section{References}

1. Kustov, A. L., Frey, A. M., Larsen, K. E., Johannessen, T., Nørskov, J. K. and Christensen, C. H., "CO Methanation over Supported 
Bimetallic Ni-Fe Catalysts: From Computational Studies Towards Catalyst Optimization,' Appl. Catal. A, 320, 98-104(2007).

2. Kopyscinski, J., Schildhauer, T. J. and Biollaz, S. M. A., "Production of Synthetic Natural Gas (SNG) from Coal and Dry Biomass A Technology Review from 1950 to 2009,' Fuel, 89, 1763-1783 (2010).

3. Rostrup-Nielsen, J. R., Pedersen, K. and Sehested, J., "High Temperature Methanation: Sintering and Structure Sensitivity,' Appl. Catal. A: Gen., 330, 134-138(2007).

4. Vitasari, C. R., Jurascik, M. and Ptasinski, K. J., "Exergy Analysis of Biomass-to-synthetic Natural Gas (SNG) Process via Indirect Gasification of Various Biomass Feedstock,' Energy, 36, 38253837(2011).

5. Liu, Z. H., Chu, B. Z., Zhai, X. L., Jin, Y. and Cheng, Y., "Total Methanation of Syngas to Synthetic Natural Gas over Ni Catalyst in a Micro-channel Reactor,' Fuel, 95, 599-605(2012).

6. Meijden, C. M. V. D., Veringa, H. J. and Rabou, L. P. L. M., "The Production of Synthetic Natural Gas (SNG): A Comparison of Three Wood Gasification Systems for Energy Balance and Overall Efficiency,' Biomass Bioenergy, 34, 302-311(2010).

7. Gröbl, T., Walter, H. and Haider, M., "Biomass Steam Gasification for Production of SNG - Process Design and Sensitivity Analysis,' Applied Energy, 97, 451-461(2012).

8. Wirth, S. and Markard, J., "Context Matters: How Existing Sectors and Competing Technologies Affect the Prospects of the Swiss Bio-SNG Innovation System," Technological Forecasting and Social Change, 78, 635-649(2011).

9. Shen, W. J., Okumura, M., Matsumura1, Y. and Haruta, M., "The Influence of the Support on the Activity and Selectivity of Pd in CO Hydrogenation,' Appl. Catal. A: Gen., 213, 225-232(2001).

10. Takenaka, S., Shimizu, T. and Otsuka, K., "Complete Removal of Carbon Monoxide in Hydrogen-rich Gas Stream Through Methanation over Supported Metal Catalysts,' Int. J. Hydrogen Energy 29, 1065-1073(2004).

11. Panagiotopoulou, P., Kondarides, D. I. and Verykios, X. E., "Selective Methanation of CO over Supported Noble Metal Catalysts: Effects of the Nature of the Metallic Phase on Catalytic Performance,' Appl. Catal. A: Gen., 344, 45-54(2008).

12. Panagiotopoulou, P., Kondarides, D. I. and Verykios, X. E., "Selective Methanation of CO over Supported Ru Catalysts,' Appl. Catal. B: Environ., 88, 470-478(2009).

13. Kowalczyk, Z., Stołecki, K., Raróg-Pilecka, W., Miśkiewicz, E., Wilczkowska, E. and Karpiński, Z., "Supported Ruthenium Catalysts for Selective Methanation of Carbon Oxides at Very Low $\mathrm{CO}_{x} / \mathrm{H}_{2}$ Ratios,' Appl. Catal. A: Gen., 342, 35-39(2008).

14. Utaka, T., Takeguchi, T., Kikuchi, R. and Eguchi, K., "CO Removal from Reformed Fuels over $\mathrm{Cu}$ and Precious Metal Catalysts," Appl. Catal. A: Gen., 246, 117-124(2003).

15. Tsai, Y. T., Mo, X. H. and Goodwin Jr, J. G., "The Synthesis of Hydrocarbons and Oxygenates During CO Hydrogenation on $\mathrm{CoCuZnO}$ Catalysts: Analysis at the Site Level Using Multiproduct SSITKA,' J. Catal., 285, 242-250(2012).

16. Sabatier, P. and Senderens, J. B., "New Synthesis of Methane," Acad. Sci., 134, 514-516(1902).

17. Morl, T., Masuda, H. and Imal, H., "Kinetics, Isotope Effects, and Mechanism for the Hydrogenation of Carbon Monoxide on Supported Nickel Catalysts,' J. Phys. Chem., 86, 2753-2760(1982).
18. Fujitani, S.-I., Takezawa, N., Uchijima, T. and Nakamura, J., "Methanol Synthesis by Hydrogenation of $\mathrm{CO}_{2}$ over a $\mathrm{Zn}$-deposited Cu(111): Formate Intermediate,' Chem. Eng. J., 68, 63-38(1997).

19. Mo, X. H., Gao, J. and Goodwin Jr, J. G., " Effect of Component Interaction on the Activity of $\mathrm{Co} / \mathrm{CuZnO}$ for $\mathrm{CO}$ Hydrogenation,' Catalysis, 285, 208-215(2012).

20. Znak, L., Stolecki, K. and Zieliński, J., "The Effect of Cerium, Lanthanum and Zirconium on Nickel/alumina Catalysts for the Hydrogenation of Carbon Oxides,' Catal. Today, 101, 65-71(2005).

21. $\mathrm{Hu}, \mathrm{X}$. and $\mathrm{Lu}, \mathrm{G} . \mathrm{X}$., "Inhibition of Methane Formation in Steam Reforming Reactions Through Modification of Ni Catalyst and the Reactants,' Green Chem., 11, 724-732(2009).

22. Gao, J., Mo, X. H., Chien, A. C.-Y., Torres, W. and Goodwin Jr, J. G., "CO Hydrogenation on Lanthana and Vanadia Doubly Promoted Rh/SiO 2 Catalysts,' Catalysis, 262, 119-126(2009).

23. Wu, R. F., Zhang, Y., Wang, Y. Z., Gao, C. G. and Zhao, Y. X., J. Fuel Chem. Tech., 37, 578-582(2009).

24. Wang, Y. Z., Wu, R. F. and Zhao, Y. X., "Effect of $\mathrm{ZrO}_{2}$ Promoter on Structure and Catalytic Activity of the $\mathrm{Ni} / \mathrm{SiO}_{2}$ Catalyst for CO Methanation in Hydrogen-rich Gases,' Catal. Today, 158, 470-474(2010).

25. Karaselçuk, R., İnci İşli, A., Erhan Aksoylu, A., İlsen Önsan Z., "CO Hydrogenation over Bimetallic Nickel-vanadium Catalysts," Appl. Catal. A: Gen., 192, 263-271(2000).

26. Kip, B. J., Smessts, P. A. T., Grondelle, J. and Van, Prins R., "Hydrogenation of Carbon Monoxide over Vanadium Oxide-promoted Rhodium Catalysts", Appl. Catal., 33, 181-208(1987).

27. Ishihara, T., Eguchi, K. and Arai, H., "Hydrogenation of Carbon Monoxide over $\mathrm{SiO}_{2}$-supported $\mathrm{Fe}-\mathrm{Co}$, $\mathrm{Co}-\mathrm{Ni}$ and Ni-Fe Bimetallic Catalysts,' Appl. Catal., 30, 225-238(1987).

28. Wang, J. J., Chernavskii, P. A., Khodakov, A. Y. and Wang, Y., "Structure and Catalytic Performance of Alumina-supported Coppercobalt Catalysts for Carbon Monoxide Hydrogenation,' Catalysis, 286, 51-61(2012).

29. Zhao, J. J., Zong, Z. M., Xie, H. S., Liu, T., Li, J. J., Wang, T. T. and Wei, X. Y., Mining Science and Technology (China), 20, 296-311(2010).

30. Boellard, E., Scheur, F. Th., Kraan, and A. M., Geus, J. W., "Preparation, Reduction, and $\mathrm{CO}$ Chemisorption Properties of Cyanidederived CuxFe $/ \mathrm{Al}_{2} \mathrm{O}_{3}$ Catalysts,' Appl. Catal. A, 171, 333-350(1998).

31. Fujitani, T., Nakamura, I., Ueno, S., Uchijima, T., Nakamura, J., J. Appl. Surf. Sci., 122, 583-586(1997).

32. Lin, M. G., Fang, K. G., Li, D. B. and Sun, Y. H., "CO Hydrogenation to Mixed Alcohols over co-precipitated Cu-Fe Catalysts,' Catal. Commun., 9, 1869-1873(2008).

33. Yu, Y., Jin, G. Q., Wang, Y. Y. and Guo, X. Y., "Synthetic Natural Gas from CO Hydrogenation over Silicon Carbide Supported Nickel Catalysts,' Fuel Process. Technol., 92, 2293-2298(2011).

34. Jin, G. Q. and Guo, X. Y., "Synthesis and Characterization of Mesoporous Silicon Carbide," Micropor. Mesopor. Mater., 60, 207212(2003).

35. Ni, Y. H., Wang, F., Liu, H. J., Liang, Y. Y., Yin, G., Hong, J. M., $\mathrm{Ma}, \mathrm{X}$. and $\mathrm{Xu}, \mathrm{Z}$., "Fabrication and Characterization of Hollow Cuprous Sulfide $\left(\mathrm{Cu}_{2}-\mathrm{xS}\right)$ Microspheres by a Simple Templatefree Route,' Inorg. Chem. Commun., 6, 1406-1408(2003).

36. Zhang, J. G., Wang, H. and Dalai, A. K., "Development of Stable Bimetallic Catalysts for Carbon Dioxide Reforming of Meth- 
ane,' Catalysis, 249, 300-310(2007).

37. Czekaj, I., Loviat, F., Raimondi, F., Wambach, J., Biollaz, S. and Wokaun, A., "Characterization of Surface Processes at the Nibased Catalyst During the Methanation of Biomass-derived Synthesis Gas: X-ray Photoelectron Spectroscopy (XPS),' Appl. Catal. A: Gen., 329, 68-78(2007).

38. Yu, Z. B., Qiao, M. H., Li, H. X. and Deng, J. F., "Preparation of Amorphous Ni-Co-B Alloys and the Effect of Cobalt on Their Hydrogenation Activity,' Appl. Catal. A: Gen., 163, 1-13(1997).

39. Petrov, K. and Will, G., "A New Cobalt-nickel Oxide Spinel Prepared Under High Pressure in An Oxygen Atmosphere,' J. Mater. Sci. Lett., 6, 1153-1155(1987).

40. Engbæk, J., Lytken, O., Nielsen, J. H. and Chorkendorff, I., “CO Dissociation on Ni: The Effect of Steps and of Nickel Carbonyl," Surf. Sci., 602, 733-743(2008).

41. Hayes, R. E., Thomas, W. J. and Hayes, K. E., "A Study of the Nickel-catalyzed Methanation Reaction,' Catalysis, 92, 312-326 (1985).

42. Mo, X. H., Tsai, Y.-T., Gao, J., Mao, D. S. and Goodwin, Jr J. G., "Effect of Component Interaction on the Activity of $\mathrm{Co} / \mathrm{CuZnO}$ for CO Hydrogenation,' Catalysis, 285, 208-215(2012).

43. Yu, Y., Jin, G. Q., Wang, Y. Y. and Guo, X. Y., "Synthesis of Natural Gas from CO Methanation over SiC Supported Ni-Co Bimetallic Catalysts,' Catal. Commun., 31, 5-10(2013).
44. Xu, J. K., Zhou, W., Li, Z. J., Wang, J. H. and Ma, J. X., "Biogas Reforming for Hydrogen Production over Nickel and Cobalt Bimetallic Catalysts,' Int. J. Hydrogen Energy, 34, 6646-6654(2009).

45. Li, L., Lu, P., Yao, Y. and Ji, W. J., "Silica-encapsulated Bimetallic Co-Ni Nanoparticles as Novel Catalysts for Partial Oxidation of Methane to Synga,' Catal. Commun., 26, 72-77(2012).

46. Zhu, J. Q., Peng, X. X., Yao, L., Shen, J., Tong, D. M. and Hu, C. W., "The Promoting Effect of $\mathrm{La}, \mathrm{Mg}$, $\mathrm{Co}$ and $\mathrm{Zn}$ on the Activity and Stability of $\mathrm{Ni} / \mathrm{SiO}_{2}$ Catalyst for $\mathrm{CO}_{2}$ Reforming of Methane,' Int. J. Hydrogen Energy, 36, 7094-7104(2011).

47. Hernández, R. P., Galicia, G. M., Anaya, D. M., Palacios, J., Chavez, C. A. and Alatorre, J. A., "Synthesis and Characterization of Bimetallic $\mathrm{Cu}-\mathrm{Ni} / \mathrm{ZrO}_{2}$ Nanocatalysts: $\mathrm{H}_{2}$ Production by Oxidative Steam Reforming of Methanol,' Int. J. Hydrogen Energy, 38, 4569-4576 (2008)

48. Lee, J. H., Lee, E. G., Joo, O. S. and Jung, K. D., "Stabilization of $\mathrm{Ni} / \mathrm{Al}_{2} \mathrm{O}_{3}$ Catalyst by $\mathrm{Cu}$ Addition for $\mathrm{CO}_{2}$ Reforming of Methane,' Appl. Catal. A: Gen., 289, 1-6(2004).

49. Boellard, E., Scheur, F. Th., Kraan, A. M. and Geus, J. W., Appl. Catal. A: Gen., 171, 333-350(1998).

50. Chen, J. L., Qiao, Y. H., Li, Y. D., "Methanation Sites on a Low Loading Ni/ $/ \mathrm{Al}_{2} \mathrm{O}_{3}$ Catalyst," Appl. Catal. A: Gen., 337, 148-154 (2008). 